\title{
Prenatal Diagnosis of Glycogen Storage Disease Type II: Enzyme Assay or Mutation Analysis?
}

\author{
WIM J. KLEIJER, MAGNA VAN DER KRAAN, MARIAN A. KROOS, JOHANNA E. M. GROENER, \\ OTTO P. VAN DIGGELEN, ARNOLD J. J. REUSER, AND ANS T. VAN DER PLOEG \\ Department of Clinical Genetics, University Hospital, Erasmus University, P.O. Box 1738, 3000 DR \\ Rotterdam, The Netherlands [W.J.K., M.V.D.K., M.A.K., O.P.V.D., A.J.J.R.], Department of Pediatrics, \\ University Hospital, Leiden, The Netherlands [J.E.M.G.], and Department of Pediatrics, Sophia Children's \\ Hospital, University Hospital, Rotterdam, The Netherlands [A.T.V.D.P.]
}

\begin{abstract}
Two mutations in the lysosomal $\alpha$-glucosidase gene, a single base pair deletion $(\Delta \mathrm{T} 525)$ and a deletion of exon 18 , have recently been identified with a relatively high incidence in Caucasian patients with glycogen storage disease type II (GSD II). Prenatal diagnosis was made in a pregnancy of consanguineous parents of a child with GSD II. The $\Delta$ T525 deletion was demonstrated in this family but unexpectedly in only one of the parents. The absence of the $\Delta$ T525 deletion in DNA isolated from the chorionic villi and a normal $\alpha$-glucosidase activity
\end{abstract}

\section{ABSTRACT}

indicated that the fetus was not affected. The possible role of mutation analysis in the prenatal diagnosis of GSD II is discussed in the light of our previous experience from a series of 100 prenatal diagnoses for this disorder by enzyme analysis. (Pediatr Res 38: 103-106, 1995)
Abbreviations
GSD II, glycogen storage disease type II
PCR, polymerase chain reaction

GSD II (Pompe's disease) is a lysosomal glycogen storage disorder caused by the deficiency of acid $\alpha$-glucosidase (EC 3.2.1.20) $(1,2)$. The disease is inherited as an autosomal recessive trait with location of the $\alpha$-glucosidase gene (GAA) at position 17q23-25. Heterogeneity is found both at the clinical and the molecular level (3-6). The clinical spectrum shows the severely affected infantile patients at one end. They present shortly after birth with a fastly progressive muscle weakness and a hypertrophic cardiomyopathy eventually leading to cardiorespiratory failure within the first year of life. At the other extreme of the spectrum there are late-onset patients experiencing muscle weakness and respiratory problems only late in adult life. The $\alpha$-glucosidase activity is virtually absent in infantile GSD II, whereas the great majority of patients with the adult type of this disease have considerable residual enzyme activity $(6-8)$.

Various mutations in the GAA gene leading to the disease have been identified. Point mutations as well as smaller and larger deletions and insertions were encountered (for review, see Ref. 6). Most patients appear to be compound heterozygotes. Recently we found that two mutations which completely prohibit the realization of $\alpha$-glucosidase activity, occur with a relatively high incidence among European patients. These

Received December 22, 1994; accepted February 23, 1995.

Correspondence: Dr. W. J. Kleijer, Department of Clinical Genetics, Erasmus University, P.O. Box 1738, 3000 DR Rotterdam, The Netherlands.

Manuscript dedicated to Professor H. K. A. Visser in honor of his retirement. mutations are the single base pair deletion $\Delta \mathrm{T} 525$, causing premature termination at nucleotide 658-660 (9), and a deletion of exon 18 (10-12). The practicability of DNA analysis for prenatal diagnosis was tested in the pregnancy of the parents of an infantile GSD II patient who was a compound heterozygote for $\Delta \mathrm{T} 525$ and a second unidentified mutation. Mutation analysis was performed in addition to routine enzyme assay on the chorionic villi. The merits of DNA analysis versus enzyme analysis for prenatal diagnosis of GSD II are discussed.

\section{CASE HISTORY}

The mother is gravida 5 para 2 . As indicated by the pedigree of family "O" (Fig. 1) the parents are consanguineous. The family history reveals no other congenital disorders. The first pregnancy was uneventful, and a healthy girl was born. Also the second pregnancy seemed without problems, but shortly after birth symptoms of infantile GSD II became apparent. There was severe generalized hypotonia, poor facial expression, progressive cardiac enlargement with decreased contractility. On ECG a characteristic short PQ interval was noticed. The tongue and liver were enlarged due to storage of glycogen. A deficiency of lysosomal $\alpha$-glucosidase activity was found in lymphocytes and fibroblasts, confirming the diagnosis. The baby died eventually at the age of 5 mo of cardiorespiratory failure. In the third and fourth pregnancy prenatal diagnosis 


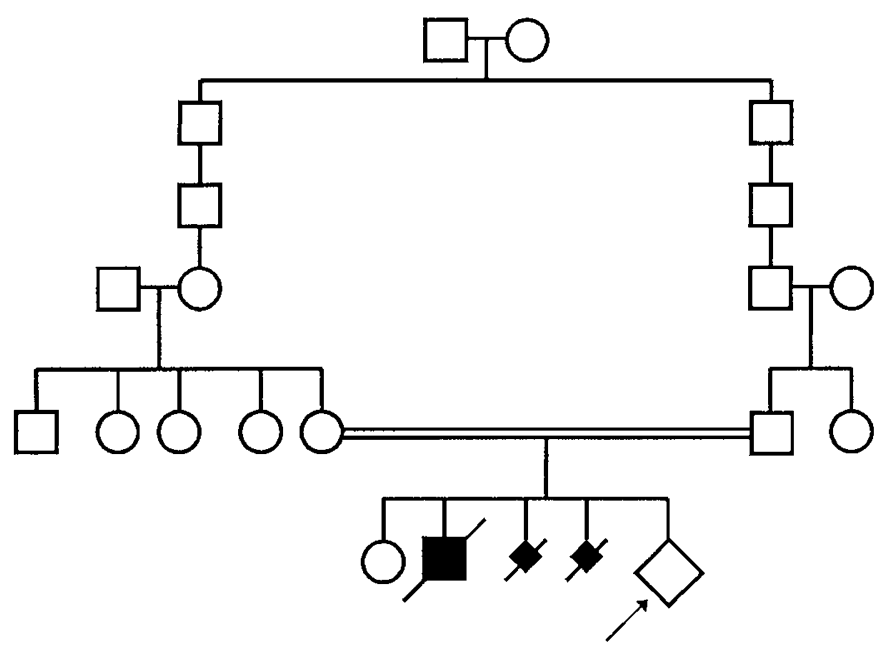

Figure 1. Pedigree of family "O." The pregnancy under study is indicated by an arrow.

was performed by enzyme analysis. In both cases the fetus appeared to be affected, and the pregnancies were terminated. The diagnosis made on chorion villi was confirmed on fibroblasts derived from the aborted fetuses. Recently the mother became pregnant again and the third prenatal diagnosis was done by chorionic villus sampling in the 12th wk of gestation.

\section{METHODS}

Sample preparation and enzyme assay. Chorionic villi from the three investigated pregnancies (11-12th wk of gestation) of Mrs. "O" were sampled in the University Hospital, Rotterdam, inspected under a microscope, selected, and washed in saline. For enzyme assay the villi (10-15 $\mathrm{mg}$, wet weight) were homogenized in $100 \mu \mathrm{L}$ water in a Potter tube and then sonicated (final protein concentrations $3 \mathrm{mg} / \mathrm{mL}$ ).

Half of the 100 other chorionic villus and amniotic fluid samples from pregnancies at risk for GSD II was also received from this hospital, whereas the other half was sent from 13 different, mainly European, countries. Amniotic fluid cells were cultured in Ham's F10 medium with $20 \%$ FCS and used for enzyme assay in their first or second passage. Amniotic fluid cells and fibroblasts were harvested $7 \mathrm{~d}$ after the last trypsinization and homogenized in water by sonication.

$\alpha$-Glucosidase was assayed by incubation of $10 \mu \mathrm{L}$ homogenate containing $10-30 \mu \mathrm{g}$ protein with $20 \mu \mathrm{L}$ of a substrate solution, containing $2.2 \mathrm{mM}$ 4-methylumbelliferyl $\alpha$-glucoside in $0.2 \mathrm{M}$ sodium acetate buffer, $\mathrm{pH} 4.0$, for $1 \mathrm{~h}$ at $37^{\circ} \mathrm{C}$.

Mutation analysis. DNA from leukocyte and fibroblast pellets was extracted as described elsewhere (13). A slightly different procedure was used for the extraction of DNA from a chorionic villus homogenate, as prepared for enzyme assay (see above). Of this homogenate $40 \mu \mathrm{L}$ was used for enzyme and protein assay and approximately $60 \mu \mathrm{L}$ for DNA extraction. To this latter aliquot $120 \mu \mathrm{L}$ of SE buffer $(75 \mathrm{mM} \mathrm{NaCl}$, $25 \mathrm{mM}$ EDTA, pH 8.0) were added together with $10 \mu \mathrm{L}$ proteinase $\mathrm{K}(10 \mathrm{mg} / \mathrm{mL})$ and $7.5 \mu \mathrm{L}$ SDS $20 \%$. After $5 \mathrm{~h}$ at $37^{\circ} \mathrm{C}, 80 \mu \mathrm{L} 6 \mathrm{M} \mathrm{NaCl}$ were added to precipitate proteins. The supernatant $\left(10 \mathrm{~min}, 12,000 \mathrm{rpm}\right.$ at $\left.4^{\circ} \mathrm{C}\right)$ was transferred to a clean tube, and DNA was precipitated with $160 \mu \mathrm{L}$ isopropa- nol and collected by centrifugation (10 min at $12,000 \mathrm{rpm})$. The DNA pellet was washed with $70 \%$ ethanol and dissolved in $25 \mu \mathrm{L}$ Tris- $\mathrm{HCl}, \mathrm{pH}$ 7.5. The DNA concentration was 0.36 $\mu \mathrm{g} / \mu \mathrm{L}$.

A 400-bp genomic DNA fragment around $\triangle \mathrm{T} 525$ was PCR amplified using a sense primer in exon 2 (AGAGCAGTGCCCACACAGTC) and an antisense primer in intervening sequence II (ACCCCAAGCTTGTGAGGTGC). The PCR conditions were as previously described (10). The PCR products and DdeI fragments were analyzed by electrophoresis on 3\% metaphor-agarose (FMC Bioproducts, Philadelphia, PA).

\section{RESULTS}

Enzyme analysis. In the past 20 y, 100 prenatal diagnoses have been made in our center in pregnancies at risk for infantile GSD II. In the first decade all investigations were performed on cultured amniocytes, whereas after 1984 most of the prenatal diagnoses were made by direct analysis of chorionic villi. Table 1 summarizes the results of $\alpha$-glucosidase assays in all of these cases. They show practically complete absence of $\alpha$-glucosidase activity in amniocytes (11 cases) and uncultured chorionic villi (10 cases) from affected pregnancies. Thus, there is $l$ ) no interference of other (e.g. neutral) $\alpha$-glucosidases (14-16) and 2) no significant contribution of maternal tissue or enzyme in carefully selected chorionic villus samples (17). In all other pregnancies $(n=33+46$; Table 1$)$ the diagnosis of an unaffected fetus was made. Several of these cases showed reduced activity compared with the control range, which is in accordance with heterozygosity. Most important is that there appears to be unequivocal distinction between affected and unaffected fetuses in chorionic villi as well as amniocytes.

$\alpha$-Glucosidase activities in chorionic villi of the three investigated pregnancies of one mother (family "O," Fig. 1) are presented separately in Table 2 . An almost complete deficiency in the first two pregnancies indicated that the fetuses were affected; both pregnancies were terminated, and the $\alpha$-glucosidase deficiencies were confirmed in the cultured fetal fibroblasts. In the third pregnancy a high-normal $\alpha$-glucosidase activity predicted a normal fetus; the pregnancy is continuing.

Mutation analysis. At the time of the third prenatal diagnosis in family "O" we were aware of two common mutations in GSD II, i.e. the deletion of exon 18 and the single base deletion $\Delta \mathrm{T} 525$ in exon 2 . The latter mutation was found in the index patient in family "O," whereas the former was excluded. It was decided to test the applicability of mutation analysis in this pregnancy. The chorionic villi sample was handled routinely as

Table 1. $\alpha$-Glucosidase activities in 100 pregnancies at risk for GSD II

\begin{tabular}{lcc}
\hline & \multicolumn{2}{c}{ Activity* } \\
\cline { 2 - 3 } Diagnosis & $\begin{array}{c}\text { Chorionic villi } \\
(n=43)\end{array}$ & $\begin{array}{l}\text { Amniotic fluid } \\
\text { cells }(n=57)\end{array}$ \\
\hline Affected & $0.7-2.4(n=10)$ & $0.0-1.0(n=11)$ \\
Unaffected & $13-258(n=33)$ & $7.5-48(n=46)$ \\
Controls & $90-260(n=45)$ & $10-56(n=94)$ \\
& $\overline{\mathrm{A}}=163 \mathrm{SD} 44$ & $\overline{\mathrm{A}}=29 \mathrm{SD} 11$ \\
\hline
\end{tabular}

* Nanomoles $/ \mathrm{h} / \mathrm{mg}$ of protein $\overline{\mathrm{A}}=$ mean activity. 
Table 2. Prenatal diagnosis by enzyme analysis in three successive pregnancies at risk

\begin{tabular}{ccc}
\hline & \multicolumn{2}{c}{$\alpha$-Glucosidase activity* } \\
\cline { 2 - 3 } Tissue & Family "O" & Control range \\
\hline Chorionic villi & 1.3 & $90-260$ \\
Pregnancy 1 & 1.1 & $(n=45)$ \\
Pregnancy 2 & 255 & \\
Pregnancy 3 & & $42-160$ \\
Fibroblasts & 0.3 & $(n=84)$ \\
Index patient $\dagger$ & 0.5 & \\
Fetus 1 & 0.4 & \\
Fetus 2 & & \\
\hline
\end{tabular}

$*$ Nanomoles/h/mg of protein.

$\dagger$ Fibroblasts of the parents were not available; leukocytes exhibited slightly reduced activity in accordance with heterozygosity but ruling out the possibility of a pseudodeficiency mutation in the second allele.

for enzyme assay, and a homogenate was made in water by sonication. DNA was extracted from this homogenate. As controls DNA was extracted from cultured fibroblasts from the index patient, the two affected fetuses, and from leukocyte pellets from the parents. In addition we included a DNA sample of a patient compound heterozygote for the $\Delta \mathrm{T} 525$ mutation. Mutation analysis, based on the loss of a DdeI site, identified the mother, the index patient, and the affected fetus (third pregnancy; PD\#1) as carriers of $\Delta \mathrm{T} 525$ (Fig. 2).

Although the father was related to the mother, he did not carry the $\Delta$ T525 deletion. Not knowing the $\alpha$-glucosidase mutation of the father, the DNA analysis was only partially informative. The index patient and the affected fetus in the third (PD\#1; Fig. 2) and fourth pregnancy (not shown) appeared to have inherited the $\Delta$ T525 allele from the mother. The fetus in the present, fifth pregnancy $(P D \# 3)$ had not inherited the $\Delta$ T525 allele of the mother. Based on this DNA analysis alone, the index patient and the affected fetuses in the first and second prenatal diagnoses would have been identified as either

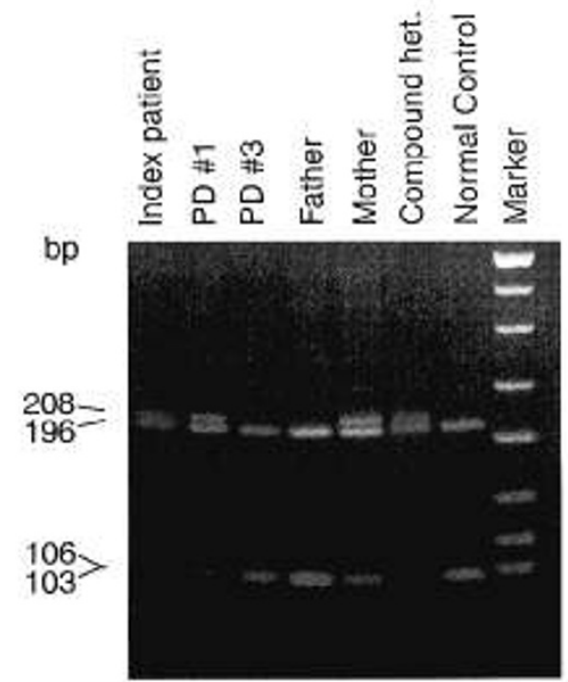

Figure 2. DdeI restriction enzyme analysis of $\Delta T 525$. A fragment of exon 2 containing the mutation site was PCR amplified and digested with Ddel. This generates a constant fragment of $196 \mathrm{bp}$. The normal fragments of 106 and 103 bp are replaced by a 208 -bp fragment when the mutation is present. $P D$ indicates prenatal diagnosis. carrier or affected, whereas the outcome of the third prenatal diagnosis would be a carrier or homozygote normal.

\section{DISCUSSION}

Prenatal diagnosis has been performed since the early $1970 \mathrm{~s}$ by amniocentesis in the 16th wk (18) and since 1984 by chorionic villus sampling in the $10-12$ th wk $(14,17)$. In this period we have experienced that a prenatal diagnosis for infantile GSD II can be made reliably using a simple fluorometric assay of lysosomal $\alpha$-glucosidase. The recent finding of two relatively common mutations causing infantile GSD II ( $\Delta$ T525 and $\Delta$ exon 18) (9-12) has opened the practical possibility for carrier detection and prenatal diagnosis by $\mathrm{mu}-$ tation analysis in affected families. In the family under study the $\Delta$ T525 deletion was demonstrated indeed, but unexpectedly this deletion was found in only one of the consanguineous parents (the mother) and in only one of the alleles of the affected offspring. Thus, despite consanguinity, the two alleles causing GSD II in the offspring are not derived from a common ancestor.

Mutation analysis in the ongoing pregnancy demonstrated the absence of the mother's $\Delta \mathrm{T} 525$ deletion in DNA from chorionic villi, which excluded that the fetus would be affected. Obviously knowledge of both mutations would have been needed to establish whether the fetus is a heterozygote carrying the father's mutation or has the homozygote normal genotype, as suggested by the high-normal $\alpha$-glucosidase activity in the villi.

The presentation of this first prenatal investigation for GSD II by DNA analysis shows that both mutation analysis and classical enzyme diagnosis may reliably be done on chorionic villi. The question may be raised which of the two approaches, if not both, should be chosen in the future. Obviously mutation analysis would be preferred for disorders in which the enzyme assay is complicated and error-prone. However, neither applies to $\alpha$-glucosidase: the assay using artificial 4-methylumbelliferyl- $\alpha$-glucoside as a substrate is specific, reliable, and quick. A definite diagnosis can be made within a few hours after chorionic villus sampling. Mutation analysis, on the other hand, requires the identification of the mutations in both parents before prenatal diagnosis. This necessitates laborious investigation and may not succeed if the common mutations are not involved.

Mutation analysis may be of major importance for prenatal diagnosis, if the measured enzyme activity in villi (or amniocytes) is well below the expected heterozygote range and near the patient's range. In principle this could be caused by maternal tissue admixture in the villus sample in the case of an affected fetus. Although we have not experienced significant interference from maternal tissue, neither in the prenatal diagnoses for GSD II nor in the large series for other metabolic disorders, this complication cannot be ruled out completely. Mutation analysis may exclude the presence of maternal tissue by demonstrating the absence of the maternal mutation as was done in the pregnancy under study in this report (Fig. 2). Other maternal markers can be tested when needed. A second cause of very low enzyme activity could be compound heterozygosity for an infantile GSD II mutation and a so-called "pseudo- 
deficiency" mutation in the second allele leading to $\alpha$-glucosidase deficiency but not to disease (19).

Such a "pseudodeficiency" mutation is well known in the arylsulfatase A gene, and its high incidence (approximately 10\%) has caused considerable complications in pre- and postnatal diagnosis of metachromatic leukodystrophy (20). We have recently investigated a family in which the healthy mother of an infantile GSD II patient exhibited an $\alpha$-glucosidase activity which was only slightly above the level in her affected child. Most likely this mother carries on her second allele a pseudodeficiency mutation or perhaps a mutation associated with adult type GSD II. In this situation mutation analysis would be required for prenatal diagnosis to distinguish between a homozygote for infantile GSD II (like the affected child) and a compound with one infantile mutation and the pseudodeficiency mutation on the second allele (like the mother). For both situations described above we emphasize that the DNA analysis can be performed on the remainder of a villus homogenate prepared for enzyme assay, as in the present study of the $\Delta$ T525 mutation.

A potential advantage of mutation analysis is its $100 \%$ reliable prediction of the genetic status of the fetus, including heterozygosity. However, is it important for people to know that they are carriers, and is it desirable to have this information available even before birth? In most populations the incidence of infantile GSD II is estimated at 1 in 50,000, which implies a carrier frequency of 1 in 100 and a $0.25 \%$ risk that a proven carrier generates an affected child. In some populations with a higher incidence and especially those with a tradition of consanguineous marriage, the relevance of carrier detection is evident.

In conclusion we think that, for routine prenatal diagnosis for GSD II, enzyme analysis on chorionic villi is the option of choice. For exceptional cases mutation analysis is advised in addition to enzyme analysis.

Acknowledgments. We thank Prof. Dr. J. Rohmer (Leiden) and Dr. P.D. Maaswinkel-Mooij (Leiden) for referring the family described in this article.

\section{REFERENCES}

1. Pompe JC 1932 Over idiopathische hypertrophie van het hart. Ned Tijdschr Geneeskd 76:304-311
2. Hers HG 1963 Alpha-glucosidase deficiency in generalized glycogen-storage disease (Pompe's disease). Biochem J 86:11-16

3. Engel AG 1986 Acid maltase deficiency. In: Engel AG, Banker BQ (eds) Basic and Clinical Myology. McGraw-Hill, New York, pp 1629-1650

4. McKusick VA 1990 Glycogen storage disease II. In: Mendelian Inheritance in Man, 9th ed., The John Hopkins University Press, Baltimore, pp 1215-1218

5. Reuser AJJ, Kroos MA, Willemsen R, Swallow D, Tager JM, Galjaard H 1987 Clinical diversity in glycogenosis type II. Biosynthesis and in situ localization of acid $\alpha$-glucosidase in mutant fibroblasts. J Clin Invest 79:1689-1699

6. Reuser, AJJ, Kroos MA, Hermans MMP, Bijvoet AGA, Verbeet, MPh, Kleijer, WJ, Van der Ploeg, AT 1995. Glycogenosis type II (acid maltase deficiency). Muscle Nerve 18(suppl 3):S61-S69

7. Van der Ploeg AT, Loonen MCB, Bolhuis PA, Busch HFM, Reuser AJJ 1988 Receptor mediated uptake of acid $\alpha$-glucosidase corrects lysosomal glycogen storage in cultured skeletal muscle. Pediatr Res 24:90 -94

8. Van der Ploeg AT, Bolhuis PA, Wolterman RA, Visser WJ, Loonen MCB, Busch HFM, Reuser AJJ 1987 Prospect for enzyme therapy in glycogenosis II variants: A study on cultured muscle cells. J Neurol 235:392-396

9. Hermans MMP, de Graaff E, Kroos MA, Mohkamsing S, Eussen BJ, Joosse M, Willemsen R, Kleijer WJ, Oostra BA, Reuser AJJ 1994 The effect of a single base pair deletion ( $\triangle \mathrm{T} 525$ ) and a C1634T missense mutation (Pro545Leu) on the expression of lysosomal $\alpha$-glucosidase in patients with glycogen storage disease type II. Hum Mol Genet 3:2213-2218

10. Van der Kraan M, Kroos MA, Joosse M, Bijvoet AGG, Verbeet MPh, Kleijer WJ, Reuser AJJ 1994 Deletion of exon 18 is a frequent mutation in glycogen storage disease type II. Biochem Biophys Res Commun 203:1535-1541

11. Huie ML, Chen AS, Sklower S, Grix AW, Hirschhorn R 1994 A de novo $13 \mathrm{nt}$ deletion, a newly identified C647W missense mutation and a deletion of exon 18 in infantile onset glycogen storage disease type II (GSD II). Hum Mol Genet 3:10811087

12. Boerkoel C, Raben N, Martiniuk F, Miller F, Plotz P 1992 Identification of a deletion common to adult and infantile acid $\alpha$-glucosidase deficiency. Am J Human Genet $51: 1367$

13. Miller SA, Dykes DD, Polesky HF 1988 A simple salting out procedure for extracting DNA from human nucleated cells. Nucleic Acids Res 16:1215

14. Grubisic A, Shin YS, Meyer W, Endres W, Becker U, Wischerath H 1986 First trimester diagnoses of Pompe's disease (glycogenosis type II) with normal outcome: Assay of acid $\alpha$-glucosidase in chorionic villus biopsy using antibodies. Clin Genet 30:298-301

15. Martiniuk F, Hirschhorn R 1981 Characterization of neutral isozymes of human $\alpha$-glucosidase. Differences in substrate specificity, molecular weight and electrophoretic mobility. Biochim Biophys Acta 658:248-261

16. Van der Ploeg AT, Kroos MA, Swallow DM, Reuser AJJ 1989 An investigation of the possible influence of neutral $\alpha$-glucosidases on the clinical heterogeneity of glycogenosis type II. Ann Hum Genet 53:185-192

17. Besancon A-M, Gastelnau L, Nicolesco H, Dumez Y, Poenaru L 1985 Prenatal diagnosis of glycogenosis type II (Pompe's disease) using chorionic villi biopsy. Clin Genet 27:479-482

18. Niermeijer MF, Koster JF, Jahodova M, Fernandes J, Heukels-Dully MJ, Galjaard H 1975 Prenatal diagnosis of type II glycogenosis (Pompe's disease) using microchemical analyses. Pediatr Res 9:498-503

19. Nishimoto J, Inui K, Okada S, Ishigami W, Hirota S, Yamano T, Yabuuchi H 1988 A family with pseudodeficiency of acid $\alpha$-glucosidase. Clin Genet 33:254-261

20. Gieselman V, Polten A, Kreijsing J, Von Figura K 1994 Molecular genetics of metachromatic leukodystrophy. J Inherit Metab Dis 17:500-509 